Acetelion, Lilly, Boehringer Ingelheim, Elizabeth Volkmann Grant/research support from: Forbius, Corbus Pharmaceuticals, Consultant of: Boehringer Ingelheim, Forbius, Speakers bureau: Boehringer Ingelheim, Dinesh Khanna Shareholder of: Eicos Sciences, Inc./Civi Biopharma, Inc., Grant/research support from: Dr Khanna was supported by NIH/NIAMS K24AR063120, Consultant of: Acceleron, Actelion, Bayer, Boehringer Ingelheim, Bristol-Myers Squibb, Corbus Pharmaceuticals, Horizon Therapeutic, Galapagos, Roche/Genentech, GlaxoSmithKline, Mitsubishi Tanabe, Sanofi-Aventis/Genzyme, UCB, Daniel Wachtlin Employee of: Employee of Boehringer Ingelheim, Martina Gahlemann Employee of: Employee of Boehringer Ingelheim, Manuel Quaresma Employee of: Employee of Boehringer Ingelheim, Margarida Alves Employee of: Employee of Boehringer Ingelheim, Oliver Distler Grant/research support from: Grants/ Research support from Actelion, Bayer, Boehringer Ingelheim, Competitive Drug Development International Ltd. and Mitsubishi Tanabe; he also holds the issued Patent on mir-29 for the treatment of systemic sclerosis (US8247389, EP2331143)., Consultant of: Consultancy fees from Actelion, Acceleron Pharma, AnaMar, Bayer, Baecon Discovery, Blade Therapeutics, Boehringer, CSL Behring, Catenion, ChemomAb, Curzion Pharmaceuticals, Ergonex, Galapagos NV, GSK, Glenmark Pharmaceuticals, Inventiva, Italfarmaco, iQvia, medac, Medscape, Mitsubishi Tanabe Pharma, MSD, Roche, Sanofi and UCB, Speakers bureau: Speaker fees from Actelion, Bayer, Boehringer Ingelheim, Medscape, Pfizer and Roche

DOI: 10.1136/annrheumdis-2020-eular.2854

\section{THU0331 INTERSTITIAL LUNG DISEASE IN SYSTEMIC SCLEROSIS: DECLINE IN FORCED VITAL CAPACITY DOES NOT PREDICT FURTHER PROGRESSION IN THE FOLLOWING PERIOD}

A. M. Hoffmann-Vold ${ }^{1}$, H. Fretheim ${ }^{1}$, B. Maurer ${ }^{2}$, M. Durheim ${ }^{1}$, Ø. Midtvedt ${ }^{1}$, M. O. Becker ${ }^{2}$, R. Dobrota ${ }^{2}$, Ø. Molberg', S. Jordan ${ }^{2}$, O. Distler ${ }^{2}{ }^{1}{ }^{1}$ Oslo University Hospital, Oslo, Norway; ${ }^{2}$ University Hospital Zurich, Zurich, Switzerland

Background: In systemic sclerosis (SSc) patients with interstitial lung disease (ILD) approximately $30 \%$ show progressive ILD. It is unknown whether a progressive ILD period is followed by further lung function decline. In clinical practice, treatment is frequently initiated after observation of lung function decline over 6-12 months and lung function stabilization at follow up is often interpreted as treatment effect.

Objectives: Assess the predictive ability of lung function decline over 12 months for further deterioration adjusted for known risk factors for ILD and treatment in two large and well characterized SSc cohorts.

Methods: Patients with SSc-ILD by HRCT, fulfilling SSc classification criteria, from the Oslo and Zurich University Hospital were included. The first period with three consecutive annual forced vital capacity (FVC) measurements (i.e. at 0, 12 and 24 months, +/- 3 months) was used. Lung function decline was assessed by absolute changes in FVC\% predicted. Moderately progressive ILD was defined as FVC decline of $>5-<10 \%$ and significantly progressive ILD as FVC decline $\geq 10 \%$ in 12 months. Candidate predictors by experts (including SSc subtype, autoantibodies, disease duration, baseline and FVC decline in the first period, extent of lung and skin (mRSS) fibrosis, CRP, reflux, tendon friction rubs, $\mathrm{O} 2$ desaturation, dyspnea) for FVC decline in the second period were tested using logistic regression analysis. Treatment included low dose corticosteroids, mycophenolate mofetil; and other immunosuppressive treatment (cyclophosphamide, Rituximab and Tocilizumab).

Results: In total, 240 SSc-ILD patients met the inclusion criteria (table). Of these 69 (29\%) SSc-ILD patients showed progressive ILD in the first 12 months period; $34(14 \%)$ with moderate $(5-10 \%)$ and $35(15 \%)$ with significant FVC decline $(\geq 10 \%)$. Independent of FVC changes in the first period, 77 (32\%) showed progressive ILD in the second period; 44 (18\%) moderate and $33(14 \%)$ significant FVC decline. Only 21 (9\%) SSc-ILD patients had two progressive periods, and $115(48 \%)$ were stable in the two 12 month's periods; all independent of treatment. In multivariable logistic regression, progressive ILD in the first period (moderate, significant or combined FVC decline) was not predictive for progression in the following period. Of all applied risk factors, only mRSS was significantly predictive for further FVC decline, also when adjusted for age, gender and treatment (OR 1.03, 95\% Cl 1.00-1.08, $\mathrm{p}=0.035$ ).

Conclusion: Decline of FVC in one 12 months period did not predict further ILD progression in the following 12 months independent of treatment. These results have important clinical implications. Firstly, a decline of lung function in one period seems not to be the right indicator for initiating treatment. Secondly, stabilization of lung function under treatment initiated after ILD progression cannot necessarily be interpreted as a treatment response on the individual patient level.

Table:

\begin{tabular}{|c|c|c|c|c|}
\hline & & First period & Both periods & \\
\hline & $\begin{array}{l}\text { SSc-ILD } \\
(\mathrm{n}=240)\end{array}$ & $\begin{array}{l}\text { ILD progres- } \\
\text { sion ( } n=69)\end{array}$ & $\begin{array}{l}\text { ILD progres- } \\
\text { sion }(n=21)\end{array}$ & $\begin{array}{l}\text { Stable ILD } \\
(\mathrm{n}=115)\end{array}$ \\
\hline Age, years (SD) & $48(14.7)$ & $49(13.8)$ & $50(14.3)$ & $46(15.3)$ \\
\hline Male, $\mathrm{n}(\%)$ & $57(24)$ & $18(26)$ & $5(24)$ & $27(24)$ \\
\hline Disease duration yrs, mean (SD) & $10.2(11.4)$ & $9.8(10.2)$ & $8.8(11.0)$ & $10.8(12.3)$ \\
\hline Diseas & $68(28)$ & $22(32)$ & $8(38)$ & $29(25)$ \\
\hline Diffuse cutaneous SSc, $n(\%)$ & $95(40)$ & $30(44)$ & $11(52)$ & $43(27)$ \\
\hline Anti-topoisomerase I Ab, n (\%) & $84(35)$ & $27(40)$ & $9(43)$ & $42(37)$ \\
\hline mRSS, mean (SD) & $10(9.3)$ & $11(10.2)$ & $16(13.0)$ & $8(8.3)$ \\
\hline CRPml, mean (SD) & $3.6(7.2)$ & $3.3(6.2)$ & $4.4(9.1)$ & $3.1(5.1)$ \\
\hline GERD, n (\%) & $148(62)$ & $44(64)$ & $15(74)$ & $70(61)$ \\
\hline FVC $\%$ predict & 90 (20.3) & $90(21.9)$ & $92(21.7)$ & $89(19.3)$ \\
\hline $\mathrm{DL}_{\mathrm{CO}} \%$ predicted & $64(17.9)$ & $64(16.6)$ & 70 (11.3) & $65(17.5)$ \\
\hline Lung fibrosis $>20 \%, n(\%)$ & $55(23)$ & $16(23)$ & $4(19)$ & $27(24)$ \\
\hline Mycophenolate Mofetil, n (\%) & $47(20)$ & $15(22)$ & $5(24)$ & $23(20)$ \\
\hline uppression, n (\%) & $79(33)$ & $22(32)$ & $9(43)$ & $42(37)$ \\
\hline Cortico & $62(26)$ & $18(26)$ & $8(38)$ & $28(24)$ \\
\hline
\end{tabular}

Disclosure of Interests: Anna-Maria Hoffmann-Vold Grant/research support from: Boehringer Ingelheim, Consultant of: Boehringer Ingelheim, Actelion, Bayer, GlaxoSmithKline, Speakers bureau: Boehringer Ingelheim, Actelion, Roche, Håvard Fretheim: None declared, Britta Maurer Grant/research support from: AbbVie, Protagen, Novartis, congress support from Pfizer, Roche, Actelion, and MSD, Speakers bureau: Novartis, Mike Durheim Grant/research support from: BI, Consultant of: BI, Speakers bureau: BI, Øyvind Midtvedt: None declared, Mike O. Becker: None declared, Rucsandra Dobrota: None declared, Øyvind Molberg: None declared, Suzana Jordan: None declared, Oliver Distler Grant/research support from: Grants/Research support from Actelion, Bayer, Boehringer Ingelheim, Competitive Drug Development International Ltd. and Mitsubishi Tanabe; he also holds the issued Patent on mir-29 for the treatment of systemic sclerosis (US8247389, EP2331143)., Consultant of: Consultancy fees from Actelion, Acceleron Pharma, AnaMar, Bayer, Baecon Discovery, Blade Therapeutics, Boehringer, CSL Behring, Catenion, ChemomAb, Curzion Pharmaceuticals, Ergonex, Galapagos NV, GSK, Glenmark Pharmaceuticals, Inventiva, Italfarmaco, iQvia, medac, Medscape, Mitsubishi Tanabe Pharma, MSD, Roche, Sanofi and UCB, Speakers bureau: Speaker fees from Actelion, Bayer, Boehringer Ingelheim, Medscape, Pfizer and Roche

DOI: 10.1136/annrheumdis-2020-eular.5755

\section{THU0332 ULTRASONOGRAPHIC EVALUATION FOR SALIVARY GLAND INVOLVEMENT IN SYSTEMIC SCLEROSIS}

J. S. Kim ${ }^{1}$, H. S. Kim², K. A. Lee ${ }^{3}{ }^{1}$ Soonchunhyang University Seoul Hospital, Seoul, Korea, Rep. of (South Korea); ${ }^{2}$ Soonchunhyang University Seoul Hospital, Internal Medicine, Seoul, Korea, Rep. of (South Korea);

${ }^{3}$ Soonchunhyang University Seoul Hospital, Interianl Medicine, Seoul, Korea, Rep. of (South Korea)

Background: While salivary gland ultrasound (SGUS) has widely used for evaluating Sjögren's syndrome, information on SGUS findings of systemic sclerosis (SSc) is limited.

Objectives: We aimed to evaluate the salivary gland involvement in patients with SSc using SGUS.

Methods: We consecutively included patients with SSc fulfilling American College of Rheumatology/European League against Rheumatism (ACR/EULAR) 2013 classification criteria, primary Sjögren's syndrome (pSS) fulfilling ACR/ EULAR 2016 classification criteria, and idiopathic sicca syndrome. All patients underwent SGUS examination using the Outcome Measures in Rheumatology (OMERACT) definition of a SGUS scoring system. The hyperechoic bands using 0-3 scoring system (none/ $<25 \%$ of the parenchyma/25-50\% />50\%) and intraglandular power Doppler signal (PDS) were assessed. Hocevar scoring system (0-48) comprising parenchymal echogenicity, homogeneity, hypoechoic areas, hyperechogenic reflections, and clearness of posterior borders were also evaluated.

Results: A total of 147 patients were included in the study: SSc $(n=59)$, pSS $(n=56)$, and idiopathic sicca syndrome $(n=32)$. The proportion of the highest OMERACT grades among the four glands $\geq 2$ were significantly higher in SSc 
(54.2\%) and pSS (62.5\%) than idiopathic sicca syndrome (3.1\%). Total OMERACT SGUS scores, total fibrosis scores, Hocevar score were significantly higher in SSc and pSS compared to idiopathic sicca syndrome (Table 1). The proportion of the highest fibrosis grades among the four glands $\geq 2$ were significantly higher in SSc $(79.7 \%)$ than pSS (62.5\%) and idiopathic sicca syndrome (46.9\%). There were no significant differences in PDS among 3 groups. Twenty-one patients $(65.6 \%)$ of 32 SSc patients with OMERACT grade $\geq 2$ were anti-centromere antibody (ACA)-positive compared with 9/27 (33.3\%) SSc patients with scores of $0-1$. The positivity of anti-Ro-60/SSA were also significantly higher in SSc patients with SGUS grade $\geq 2(37.5 \%)$ than those with SGUS scores of $0-1$ (3.7\%). In SSc group, there was no significant difference in auto-antibody profile and organ involvement between patients with fibrosis scores $\geq 2$ and those with scores $0-1$

Table 1. Characteristics of the study population included in the study

\begin{tabular}{|c|c|c|c|c|c|c|}
\hline & $\begin{array}{c}\text { SSc } \\
(n=59)\end{array}$ & $\begin{array}{l}\text { pSS } \\
(n=56)\end{array}$ & $\begin{array}{l}\text { Idiopathic } \\
\text { sicca } \\
\text { syndrome } \\
(\mathrm{n}=32)\end{array}$ & $\begin{array}{c}P \text {-value } \\
\text { (SSc vs } \\
\text { pSS) }\end{array}$ & $\begin{array}{l}P \text {-value } \\
\text { (SSc vs } \\
\text { idiopathic } \\
\text { sicca) }\end{array}$ & $\begin{array}{c}P \text {-value } \\
\text { (pSS vs } \\
\text { idiopathic } \\
\text { sicca) }\end{array}$ \\
\hline Age, mean (SD), years & $54.8(12.1)$ & $60.5(11.9)$ & $62(11.2)$ & 0.013 & 0.006 & 0.559 \\
\hline Female, $\mathrm{n}(\%)$ & $53(89.8)$ & $56(100)$ & $28(87.5)$ & 0.028 & 0.737 & 0.015 \\
\hline Anti-Ro-60/SSA, n (\%) & $13(22.0)$ & 39 (69.6) & $7(21.9)$ & $<0.001$ & 0.986 & $<0.001$ \\
\hline ACA, n (\%) & $30(30.8)$ & $8(14.3)$ & $2(6.3)$ & $<0.001$ & $<0.001$ & 0.238 \\
\hline Anti-topoisomerase, n (\%) & $16(27.1)$ & $0(0)$ & $0(0)$ & $<0.001$ & $<0.001$ & 1.000 \\
\hline $\begin{array}{l}\text { Max OMERACT US grade } \\
\geq 2, \mathrm{n}(\%)\end{array}$ & $32(54.2)$ & $35(62.5)$ & $1(3.1)$ & 0.369 & $<0.001$ & $<0.001$ \\
\hline $\begin{array}{l}\text { Total SGUS scores, median } \\
\quad(\text { IQR) }\end{array}$ & $4.0(6)$ & $7.0(8)$ & $0(1)$ & 0.231 & $<0.001$ & $<0.001$ \\
\hline $\begin{array}{l}\text { Max fibrosis US grade } \\
\geq 2, \mathrm{n}(\%)\end{array}$ & $47(79.7)$ & $35(62.5)$ & $15(46.9)$ & 0.042 & 0.004 & 0.263 \\
\hline $\begin{array}{l}\text { Total fibrosis scores, } \\
\text { median (IQR) }\end{array}$ & $6(3)$ & $6(6)$ & $4(4)$ & 0.674 & $<0.001$ & 0.006 \\
\hline $\begin{array}{l}\text { PDS sum scores of four } \\
\text { salivary glands, median } \\
\text { (IQR) }\end{array}$ & $2(5)$ & $0(4)$ & $0(2)$ & 0.131 & 0.152 & 1.000 \\
\hline
\end{tabular}

Conclusion: Based on OMERACT definitions for SGUS, more than half of the patients with SSc, especially those with ACA, had salivary gland involvement. Salivary glandular fibrosis is more prominent in patients with SSc than those with pSS and idiopathic sicca syndrome.

References:

[1] Jousse-Joulin S, et al. Video clip assessment of a salivary gland ultrasound scoring system in Sjogren's syndrome using consensual definitions: an OMERACT ultrasound working group reliability exercise. Ann Rheum Dis. 2019;78(7):967-73

Disclosure of Interests: None declared

DOI: 10.1136/annrheumdis-2020-eular.3432

\section{THU0333 CARDIOVASCULAR COMORBIDITIES ARE COMMON IN RHEUMATOID ARTHRITIS PATIENTS WHO PRACTICE LESS PHYSICAL ACTIVITY AND WHO HAVE WORSE FUNCTIONAL CAPACITY}

I. Pereira ${ }^{1}$, G. Ribas ${ }^{1}$, G. Castro ${ }^{1}$, G. Castelar ${ }^{2}$, A. B. Vargas-Santos ${ }^{2}$, C. Albuquerque ${ }^{3}$, A. P. Gomides ${ }^{3}$, M. Bertolo ${ }^{4}$, P. Louzada Jr ${ }^{5}$, R. Giorgi ${ }^{6}$, M. F. Guimarães ${ }^{7}$, S. Radominsky ${ }^{8}$, K. Bonfiglioli ${ }^{5}$, M. D. F. Sauma ${ }^{9}$, C. Brenol ${ }^{10}$, E. Coutinho ${ }^{11}$, L. Mota ${ }^{3} .{ }^{1}$ Universidade do Sul de Santa Catarina, Palhoça, Brazil; ${ }^{2}$ UFRJ, Rio de Janeiro, Brazil; ${ }^{3}$ UnB, Brasilia, Brazil; ${ }^{4}$ UNICAMP, Campinas, Brazil; ${ }^{5}$ USP, São Paulo, Brazil; ${ }^{6}$ Hospital do Servidor Público Estadual de São Paulo, São Paulo, Brazil; ${ }^{7}$ UFMG, Belo Horizonte, Brazil; ${ }^{8}$ UFPr, Curitiba, Brazil; ${ }^{9}$ UFPA, Belém, Brazil; ${ }^{10}$ UFRGS, Porto Alegre, Brazil;

${ }^{11}$ Fundação Oswaldo Cruz, Rio de Janeiro, Brazil

Background: Patients with rheumatoid arthritis have more cardiovascular comorbidities which contributes to hospitalization and mortality.

Objectives: This study aims to investigate whether there is an association between cardiovascular comorbidities in RA with subgroup of patients and clinical findings of the disease

Methods: This study is a cross-sectional part of Rheumatoid Arthritis in Real Life (REAL), which is a multicenter prospective study conducted in Brazil, involving 13 centers specialized in the care of patients with RA. All subjects met the ARA (1987) or ACR/EULAR (2010) RA classification criteria. Subjects were submitted to clinical interview with physical exam and review of medical records. A sample of 1116 patients was selected for convenience. The association between cardiovascular comorbidities (systemic arterial hypertension (HA), diabetes mellitus (DM) type2, dyslipidemia, stroke and heart failure), the clinical characteristics and laboratory parameters of RA was evaluated through chi-square hypothesis tests, Student's t-test, Fischer exact test, correlations test and ANOVA. Also, correction Bonferoni test was used for multiple comparisons. Differences were considered statistically significant only when $\mathrm{p} \leq 0.05$.

Results: $89 \%$ of the patients were female, with a mean age of 58 years. $62 \%$ of patients with RA had comorbidities, with HA the most prevalent. There were statistically significant association between cardiovascular comorbidities with age $(61.71 \pm 9.69$ years old vs $53.03 \pm 12.10)(p<0.001)$, lower educational level $(n=282 \pm 66.5 v s \quad 143 \pm 33,5) \quad(p<0.001)$, lower physical activity $(n=132 \pm 73.3$ vs $48 \pm 26.7)$ ( $p<0.001)$, disease duration $(18.5 \pm 9.75$ years vs $14.4 \pm 8.61$ ) ( $p<0.001)$, positive anti-CCP test $(60.5 \%$ vs $39.5 \%)(p=0.027)$, high clinical disease activity index CDAI) $(65.9 \%$ vs $34.1 \%)(p<0.001)$, DAS28VHS $(3.72 \pm 1.46$ vs $3.45 \pm 1.58)(p=0.008)$ and $\mathrm{HAQ}$ score $(1.00 \pm 0.76)$ vs $0.83 \pm 0.77$ $(p<0.001)$

Conclusion: The frequency of cardiovascular comorbidities is high in RA patients and is associated with age, disease duration and positive anti-CCP test. It is also important to see that these comorbidities are more common in patients with lower frequency of physical activity and lower functional capacity, higher disease activity score and lower level of education. Better control of disease activity and extensive information to patients about the importance of exercise should be parallel objectives in RA.

Disclosure of Interests: Ivanio Pereira Grant/research support from: Has received consulting fees, speaking fees and supporting for internationals congresses from Roche, Pfizer, UCB Pharma, Eli-Lilly, Abbvie and Janssen, Consultant of: Has received consulting fees, speaking fees and supporting for internationals congresses from Roche, Pfizer, UCB Pharma, Eli-Lilly, Abbvie and Janssen, Paid instructor for: Has received consulting fees, speaking fees and supporting for internationals congresses from Roche, Pfizer, UCB Pharma, Eli-Lilly, Abbvie and Janssen, Speakers bureau: Has received consulting fees, speaking fees and supporting for internationals congresses from Roche, Pfizer, UCB Pharma, Eli-Lilly, Abbvie and Janssen, Gabriela Ribas: None declared, G Castro: None declared, Geraldo Castelar Grant/research support from:: Has received consulting fees from AbbVie, Bristol-Myers Squibb, Eli Lilly, Glaxosmithkline, Janssen, Pfizer, Sanofi Genzyme and Roche, Consultant of:: Has received consulting fees from AbbVie, Bristol-Myers Squibb, Eli Lilly, Glaxosmithkline, Janssen, Pfizer, Sanofi Genzyme and Roche, Paid instructor for:: Has received consulting fees from AbbVie, Bristol-Myers Squibb, Eli Lilly, Glaxosmithkline, Janssen, Pfizer, Sanofi Genzyme and Roche, Speak ers bureau:: Has received consulting fees from AbbVie, Bristol-Myers Squibb, Eli Lilly, Glaxosmithkline, Janssen, Pfizer, Sanofi Genzyme and Roche, Ana Beatriz Vargas-Santos Grant/research support from: Has received supporting for international medical events from AbbVie and Janssen, Cleandro Albuquerque Grant/research support from: Has received personal fees and/or non-financial support from Pfizer, AbbVie, AstraZeneca, Janssen, Bristol-Myers Squibb, Roche, Novartis and UCB, Consultant of: Has received personal fees and/or non-financial support from Pfizer, AbbVie, AstraZeneca, Janssen, Bristol-Myers Squibb, Roche, Novartis and UCB, Paid instructor for: Has received personal fees and/or non-financial support from Pfizer, AbbVie, AstraZeneca, Janssen, Bristol-Myers Squibb, Roche, Novartis and UCB, Speakers bureau: Has received personal fees and/or non-financial support from Pfizer, AbbVie, AstraZeneca, Janssen, Bristol-Myers Squibb, Roche, Novartis and UCB, Ana Paula Gomides Consultant of: Abvvie, Manoel Bertolo Grant/research support from: Has participated in clinical and/or experimental studies related to this work and sponsored by Roche; has delivered speeches at events related to this work and sponsored by AbbVie and Pfizer, Paid instructor for: Has participated in clinical and/or experimental studies related to this work and sponsored by Roche; has delivered speeches at events related to this work and sponsored by AbbVie and Pfizer, Speakers bureau: Has participated in clinical and/or experimental studies related to this work and sponsored by Roche; has delivered speeches at events related to this work and sponsored by AbbVie and Pfizer, Paulo Louzada Jr Grant/research support from: Has received supporting for internationals congresses from Bristol-Myers Squibb, UCB and consulting fees from Pfizer, Paid instructor for: Has received supporting for internationals congresses from Bristol-Myers Squibb, UCB and consulting fees from Pfizer Speakers bureau: Has received supporting for internationals congresses from Bristol-Myers Squibb, UCB and consulting fees from Pfizer, Rina Giorgi: None declared, Maria Fernanda Guimarães: None declared, Sebastião Radominsky Grant/research support from: Has received consulting and speaking fees from Abbvie, Janssen, Pfizer, Roche and UCB, Consultant of: Has received 